\title{
A corpus-driven collocation analysis of degree adverb very, really, quite, and pretty
}

\section{Tantri Refa Indhiarti ${ }^{{ }^{*}}$, Erwanda Resti Chaerunnisa ${ }^{2}$}

Jurusan Bahasa dan Sastra, Fakultas Ilmu Budaya, Universitas Brawijaya, Jalan Veteran Ketawanggede, Kecamatan Lowokwaru, Kota Malang, Indonesia

Itantri.refa@ub.ac.id*; erwanda.resti@ub.ac.id²

* Corresponding author: tantri.refa@ub.ac.id

\begin{tabular}{l} 
Article History Received: September I6, 2020 Revision: October I4, 2020 Available Online: October 3I, 2020 \\
ABSTRACT \\
\hline Degree adverb is an element of intensifiers as a means for speakers to make their utterances more expressive. It provides \\
information about how much, how many, and to what extent. It seems that every degree has their preferences in terms of \\
collocations and the semantic prosody that arise. This paper examines the collocational pattern and semantic prosody of \\
degree adverbials very, really, quite, and pretty in Blog Authorship Corpus. A qualitative approach thus was employed to \\
conduct this research while a corpus method was used in collecting and analyzing the data with the help of corpus software \\
WordSmith 4.0. The data source came from Blog Authorship Corpus, a non-annotated corpus, which can be easily accessed \\
through its website. The result of the analysis has shown that all degree adverbials collocate with words from adjective, verb, \\
and adverb word classes. In this case, really and quite are seen to collocate with verbs, while at the same time really also co- \\
occurs with a preposition in a particular case. They mostly occur in the medial position, differed only by their collocations, \\
forming several different patterns. Pleasant semantic prosody favored both very and quite, while neutral and unpleasant \\
semantic prosody surrounded pretty and really, respectively.
\end{tabular}

Keywords Degree adverb, Collocation, Corpus-driven approach, Semantic prosody

\section{ABSTRAK}

Degree adverb merupakan elemen intensifiers sebagai sarana bagi penutur bahasa untuk membuat ucapannya lebih ekspresif. Elemen ini memberikan informasi tentang berapa banyak dan sejauh mana. Setiap adverbial memiliki preferensi sendiri dalam hal kolokasi dan prosodi semantik yang muncul. Penelitian berikut ini membahas pola kolokasional dan prosodi semantik adverbial very, really, quite, dan pretty di Blog Authorship Corpus. Dengan demikian pendekatan kualitatif digunakan dalam penelitian ini dengan dibantu metode korpus dalam mengumpulkan dan menganalisis data, serta perangkat lunak korpus WordSmith 4.0. Sumber data berasal dari Blog Authorship Corpus, suatu korpus yang belum mengalami proses anotasi, yang dapat dengan mudah diakses melalui situs web. Hasil analisis menunjukkan bahwa semua adverbial bersatu dengan kata-kata dari kelas kata sifat, kata kerja dan kata keterangan. Dalam hal ini, really dan quite terlihat bersebelahan dengan kata kerja, dan pada saat yang sama really juga berkolokasi dengan preposisi dalam kasus tertentu. Kedua jenis adverbial tersebut sebagian besar terjadi pada posisi medial, dibedakan dari kolokasi yang membentuk beberapa pola berbeda. Prosodi semantik yang positif meliputi adverbial very dan quite, sementara prosodi semantik yang netral dan negatif meliputi adverbial pretty dan really.

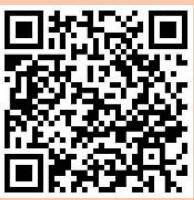

Copyright@2020, Tantri Refa I, Erwanda Resti C This is an open access article under the CC-BY-3.0 license

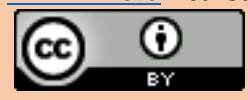

\begin{tabular}{ll}
\hline Kata Kunci & Degree adverb, Kolokasi, Pendekatan korpus, Prosodi semantik \\
\hline \hline How to Cite & Indhiarti, T. R., \& Chaerunnisa, E. R. (2020). A corpus-driven collocation analysis of degree adverb very, \\
& really, quite, and pretty. KEMBARA: Jurnal Keilmuan Bahasa, Sastra, dan Pengajarannya (e- \\
& Journal), 6(2). 226-242. doi: https://doi.org/10.22219/kembara.v6i2.13526
\end{tabular}

\section{INTRODUCTION}

An intensifier may enhance the influence of a word's emotional meaning by using adverbs, such as very, really, quite, and pretty. An adverb is used to make the meaning stronger as well as plays roles as discourse markers (Carter et al., 20II; Reicheld \& Durham, 20I4). The adverbs may add more information to a verb, an adjective, another adverb and a clause to indicate the time, manner, place, degree, and frequency of something. It is noted also that the use of the adverbs is on the rise across time (Barnfield and Buchstaller, 2010). It is due to constant change and thus raises some intriguing lexical and semantic 
puzzles for linguistics theory that have attracted interest in research. Gonzales-Diaz (20I4) scrutinized socio-stylistic mappings between characters and functions of degree adverb quite in Austen's novels through a corpus-based analysis. It is indicated that gender is the main factor determining the sociostylistic variation in the novel and female language for the stylistic stratification of quite in the novels have been drawn on $18^{\text {th }}$-century stereotypes. Furthermore, Zhiber and Korotina (2019) looked into the renewal and boundedness of intensifying adverbs in spoken discourse and newspaper language by using the Corpus of Contemporary American English (COCA) and British National Corpus (BNC). The study which was restricted to the analysis of intensifier + adjective assumes that less intensification is used in written discourse whereas more intensification is employed in spoken discourse and the decline of intensification is higher as the formality of the register increases.

Additionally, Watcher (2012) conducted a study to analyze variation of adverbial intensifers very and really in academic speech by using Michigan Corpus of Academic Spoken English (MICASE). It is assumed that there are factors affecting the use of those adverbials, such as formality. Meanwhile, Zhang (2013); Simpson \& Mendis (2003); Nakatani \& Hirschberg (1994); Deroey \& Taverniers (201 I); Charles (2006); Bolton, Nelson, \& Hung (2002) examined adverbial intensifiers terribly, awfully, horribly, and dreadfully due to their negative tendencies. The data were obtained from a synchronic and diachronic corpus of contemporary written and spoken texts retrieved from bank of English and Corpus of Late Modern English Texts. It is indicated that negative meanings dominate the four adverbials and their percentage of positive meanings eventually increase after going through historical processes. Yilmaz and Dikilitas (2017) are other researchers who highlighted that the appropriate use of adverbs remains a problem for advanced learners of English. In the study, a group of students having taken an academic writing course were selected and a guided writing activity was applied. It is known that the overused adverb of degree in the students' academic writing suggests a need for systematic explicit instruction of English adverb.

Considering all previous studies, adverbials are prominent lexical and semantic aspect in indicating the strength of meaning of utterances in which scrutinizing the collocation in the context enables the structural description and semantic categorization. It is thus in the present study which draws upon the inventories of earlier ones, the analyses of the distribution of the lexemes and their prosody to indicate subtle functional variations in the use of English is conducted.

In this research, very, really, quite, and pretty were analyzed. As the most common degree adverbials out of others, English writer often uses the four of them interchangeably. Therefore, their common occurrences make one hard to notice whether there is any specific tendency behind their usage or not. In addition, they do not bear a specific sense or meaning behind themselves to support their collocational tendencies as degree adverbials.

Adverbials serve three specific functions. As Biber et al (2002) identify, they are to tell about the circumstances of the clause, to express the speaker's feeling on said clause, and to link the clause or some part of the clause with another clause. Consequently, three main classes of adverbial can be distinguished based on those functions, i.e. circumstance adverbial, stance adverbial, and linking adverbial.

Those adverbial classes are then divided into some categories and subcategories, which function to answer several questions regarding its sentence. According to Biber et al (2002), the most common adverbial class, circumstance adverbials, have seven categories under its wing. One of them is degree adverbial category. Degree adverbial is used in purpose to answer questions like 'how far/much/many?' and 'to what extent?' or simply to intensify a certain point in the clause. These degree adverbials seem to have the same functions and features as to what Quirk et al (1985) previously illustrated as intensifiers. Quirk et al (1985) elaborate that intensifiers function to indicate a point on the intensity scale, which can be either high or low.

The category of degree adverbials is divided into more subcategories in accordance to their specific function. Biber et al (2002) state that the subcategories in question are amplifier and diminisher. Amplifier functions in purpose to strengthen the message in the clause or expresses a higher even an 
extreme scale of a certain point. On the other hand, diminisher is supposed to do the opposite, which is to reduce the strength of a claim in the clause or lowering the force of an item. These functions also applied for very, really, quite, and pretty, since the four of them are also included as degree adverbial. For example, in Blog Authorship Corpus, very is used as an amplifier in a context like 'I have a very good friend standing by my side'. In that context, the writer strengthens the quality of good. Whilst in the context, 'he is quite popular these days you know' diminisher quite is used to help the writer in lowering the quality of popular.

Based on those functions and illustrations of degree adverbials, there are many amplifiers and diminishers that can be used and often used interchangeably, making one assume that they are the same thing. However, several previous researches conducted by linguists actually suggested that every word has their own preferences in terms of collocation and semantic prosody. Begagic (2013) conducts a study which analyzed semantic preference and semantic prosody of collocation make sense. He investigated the classification of the collocation environments into negative, positive, possible, difficult, and neutral environment. Although a very clear description of semantic preference and prosody is presented in Begagic's research, the environments are not distinguished properly as some environments such as possible and difficult are neither negative nor positive. The present study thus is focused on negative, positive, and neutral environments only. In one research, Partington (2004) analyzed degree adverbials utterly, totally, completely, and entirely. The result shows that those degree adverbials are constantly followed by words like oblivious, without, forgotten, different, etc, which all describe the absence of a quality or a change of state. However, in this very same research, a different result comes up for the case of another degree adverbial, thoroughly. Despite being on the same page with the previous degree adverbials, thoroughly is mostly followed by adjectives describing emotions or state of mind like annoyed, enjoyed, happy, confused, and so on.

Interestingly, another research suggests that some amplifiers and diminishers often associated with either positive or negative preference. It is illustrated in the case of degree adverbial utterly. In his research, Louw (1993) found that utterly has a great negative preference or bad prosody as shown in the concordance drawn from 18 million words corpus at Cobuild. Displayed in their concordance lists, some words collocating with 'utterly' are demolished, meaningless, stupid, and unreasonable. These researches implied that the analysis of degree adverbial could be based on its collocational preferences, motivating the researcher to conduct this research in order to identify its preferences, specifically its collocations and semantic prosody.

Collocation was first proposed by Firth (1957) decades ago before developing years after years by many other linguists. Sinclair (2003) defines it as 'a general term for two or more words occurring near each other in a text'. While semantic prosody is defined by Louw (1993) as "the consistent aura of meaning with which the form is imbued by its collocations". Later on, Stubbs (1995) then expands the notion of semantic prosody by claiming that words also can collocate with semantic sets, as well as with positive or negative grouping words. In other words, some certain seemingly neutral words may have either positive or negative association through frequent co-occurrences with particular collocates. That being said, the collocates of degree adverbials very, really, quite, and pretty in the chosen corpus may reveal the tendencies of their collocational preferences.

On this basis, this study is to provide an overview outlining the lexical and semantic issues involving adverbials and link the knowledge of the adverbials within the context of blog and English interaction. It is in line with Long \& Christensen (2008) and Zhiber \& Korotina (2019) arguing that incorrect usage of the adverbs may lead to an unexpected pragmatic outcome. Furthermore, English collocations with adverbs have been considered the most difficult pattern because collocations are often unpredictable to recall (Huo, 20I4). In the light of the background, the present study investigate how the degree adverbials very, really, quite, and pretty collocate and how the collocates indicate the semantic prosody. 


\section{METHOD}

Qualitative approach was employed in this research combined with corpus-driven approach which was also performed by utilizing the corpus as the data source to uncover linguistic phenomena that might be overlooked without any prior assumption regarding the phenomena. In it, Jones and Waller (2015) separate corpus types into open-access corpus and make-up corpus. An open-access corpus is the online corpus available on the internet so that it can be freely accessed, namely BNC, COCA, or MICASSE, whereas a make-up corpus is a collection of data which is complied and created by using corpus analysis software such as AntConc or WordSmith.

The data of this study are sentences containing either very, really, quite, and pretty as their respective function as adverbial intensifiers with adjectives as its collocation in Blog Authorship Corpus. The data was taken from Blog Authorship Corpus which consists of collected posts of 19,320 bloggers from blogger.com in August 2004. The corpus compiles a total of 68I,288 posts and over I 40 million words which can be easily accessed and downloaded through its website (http://u.cs.biu.ac.il/ koppel/BlogCorpus.htm). It has to be understood that Blog Authorship Corpus is a non-annotated corpus, hence the corpus is not provided with either prosodic, semantic, or historical information as additional linguistic information.

The language which is used in a blog is obviously different from other genre such as an academic one, either in terms of degree of formality or the use of slangs. It is as what Nilsson (2003, cited in Nowson 2006) noted before as she found that the posts in a community of weblogs employs informal, non-standard contractions, and slangs.

In collecting the data, the steps taken were downloading the corpus from the website. Since the corpus itself is a non-annotated corpus, the data was obtained from the website in the form of .rar (Roshal Archive) file. Next is extracting the data .rar file into a folder so that each data can be accessed using corpus software in the form of .xml (eXtensible Markup Language). Then the corpus software named WordSmith 4.0 was operated to analyze the blog post compilation by selecting Concord tab and typing the keyword in Search Word Tab. The result appeared in Concordance window as shown in Figure I. Eventually, the result which is the concordance line is saved in the form of sentences containing Key Word in Context (KWIC).

\begin{tabular}{|c|c|}
\hline \multicolumn{2}{|c|}{ N Concordance } \\
\hline 1 & that this post is fair and balanced, I should do a very honest and self-effacing haiku about myself. \\
\hline 2 & up late definitely took its toll. Paul and I had a VERY low key Monday and then on Tuesday I went \\
\hline 3 & faggots! Get over here!" Two blocks later, I was very upset to see that the scumbags screaming at us \\
\hline 4 & this weekend was beautiful beyond belief. It was very intensive as I met so many of the different family \\
\hline 5 & ? Answer: they do challenges which keep them very busy. You don't have to watch a half an hour of \\
\hline 6 & burner sit quietly in the corner of my bedroom. It's very pretty when it sits quietly. 6) I love TV. Here is \\
\hline
\end{tabular}

Figure I

Concordance Lines of Adverbial Intensifier 'Very'

Once the data were collected, the collocation and semantic prosody of the adverbials are examined based on the collocates tab. In this tab, the words on the first left column are those which collocate with the degree adverbials as obtained from the concordance (see Figure 2). 


\begin{tabular}{|c|c|c|c|c|c|c|c|c|c|c|c|}
\hline Word & With||\| & Total Left & Total Right & L5 & L4 & L3 & L2 & L1 & Centre & $\mathrm{R} 1$ & $\mathrm{R} 2$ \\
\hline GOOD & very II & 1,065 & 9,615 & 255 & 239 & 219 & 217 & 135 & 0 & 8,503 & 466 \\
\hline $\mathrm{MUCH}$ & very II & 465 & 7,493 & 158 & 134 & 112 & 47 & 14 & 0 & 6.876 & 194 \\
\hline VERY & very II & 10,713 & 10,714 & 834 & 893 & 1,303 & 1,536 & 6,147 & $71,781 \mid$ & 6,147 & 1,536 \\
\hline WELL & very II & 1,273 & 6,563 & 320 & 380 & 355 & 170 & 48 & 0 & 5,650 & 213 \\
\hline NICE & very II & 557 & 5,369 & 116 & 110 & 110 & 123 & 98 & 0 & 4,848 & 202 \\
\hline LONG & very II & 401 & 3,317 & 104 & 98 & 92 & 73 & 34 & 0 & 2,859 & 192 \\
\hline INTERESTING & very II & 202 & 3,077 & 28 & 39 & 32 & 77 & 26 & 0 & 2,830 & 82 \\
\hline HAPPY & very II & 229 & 3,269 & 58 & 60 & 42 & 43 & 26 & 0 & 2,788 & 203 \\
\hline
\end{tabular}

Figure 2

Collocates of Adverbial Intensifier 'Very'

Partington's (2004) classification of semantic prosody was used to categorize the adverbials semantic prosody by selecting adjective collocates. In this case, Longman Dictionary of Contemporary English $5^{\text {th }}$ edition provided guidance to define the meaning of each collocate. In addition, each collocation in their expanded context was carefully examined to find out whether the collocation has pleasant or unpleasant meaning (see Figure 3).

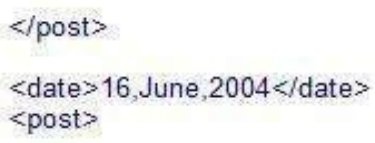

Plays and Naps I am here to say that the play we are writing for the theatre company is just a understand. After the meeting was over, I wrote the ending of the play. It was so much fun to do. $t$ I am very happy with how it all turned out. This week, Kelly and Megan, will spend time filling in so of the month and we will use their feedback and comments to fine tune any last minute problems.

Figure 3

The Expanded Context of KWIC 'Very' in Source Text Tab

\section{FINDINGS AND DISCUSSION}

In presenting the finding, it should be noted that prior to data analysis, the data were limited based on two conditions. The first condition is that the number of collocates for each degree adverbial was reduced to the point deemed enough to be representative and differed based on their total tokens. The second condition is that collocates in which degree adverbials to modify them as anything were excluded. Additionally, Longman Dictionary of Contemporary English (henceforth LDOCE) was used while the expanded context of said tokens was carefully checked in defining the meaning of each collocation.

\section{The Collocations of Degree Adverbial 'Very, Really, Quite, and Pretty'}

Collocation refers to the way a pair of words which often used or appeared together in the same context. Thus, the researcher conducted an analysis on Blog Authorship Corpus to see the collocations of degree adverbial very, really, quite, and pretty.

\section{The Collocations of Degree Adverbial 'Very'}

A total number of I7I.782 tokens of very were found in the Blog Authorship Corpus. The collocates are put in a table as follows (the following collocates have the co-occurring frequency of 100 or above and are listed in descending order of said frequency): 
Table I

The Collocates of Degree Adverbial 'Very'

Collocates

good, much, well, nice, long, interesting, happy, little, cool, hard, important, funny, first, excited, few, bad, sad, different, tired, close, soon, high, difficult, fun, small, busy, strange, often, exciting, special, proud, easy, low, cute, short, strong, large, big, similar, quickly, sweet, early, simple, best, boring, far, fast, hot, pretty, odd, weird, beautiful, late, same, old, real, last, young, lucky, clear, upset, angry, glad, quiet, impressed, interested, sorry, serious, true, smart, entertaining, cold, popular, bored, pleased, slowly, easily, sick, helpful, loud, expensive, powerful, slow, friendly, scary, attractive, useful, comfortable, rare, likely, badly, pleasant, kind, annoying, disappointed, stupid, poor, near, confused, enjoyable, amusing, relaxing, nervous, rarely, wrong, dark, impressive, seriously, sexy, personal, talented, dangerous, nicely, careful, successful, frustrating, uncomfortable, grateful, deep, intelligent, warm, productive, confusing, surprised, drunk, emotional, painful, tiring, disturbing, hungry, thankful, great, scared, carefully, open, bright, creative, sensitive, active, limited, sure, heavy, strongly, specific, clean, lazy, quick, tasty, thin, worried, common, lonely, clever, concerned, complicated, effective, light, positive, obvious, afraid, loudly, sleepy, tough, tight, depressing, tall, healthy, pissed, familiar, basic, clearly, depressed, unique, mad, cheap, weak, frustrated, curious, full, dear, fond, fine, informative, stressful, rich, unhappy, supportive, awesome, generous, new, intense, moving, nearly, polite, handsome, patient, fortunate, lovely, calm, ill, unusual, closely, romantic, brief, possible, shy, famous, rude, random, silly, wise, eventful, sore, confident, encouraging, realistic, rough complex, neat

Table I derived from the corpus shows that degree adverbial very co-occurs with various words as its collocates. In its occurrences, it is noted that the collocations were found either at the end of the clause or in the middle of the clause. To ease the elaboration, illustration of the patterns is given based on the types of collocates as it is observed that the collocates of degree adverbial very consists of words coming from either adjective or adverb word class. The first pattern to be identified is when the collocations of degree adverbial very and adjective collocates are placed at the end of the clause with either noun complimented by linking verb or noun complimented with verb and pronoun precede the collocations. See the following examples:

(I) The directors' notes are very good.

(2) This realization makes me very sad.

Another pattern emerges when the collocations are placed in the middle of the clause. The said collocations are followed by a noun phrase with a determiner being placed before the collocations, as in:

(3) He's a very intelligent guy.

(4) We have a very nice discussion.

(5) I got to meet some very interesting people.

Or the collocations can be followed by either infinitive or prepositional phrase as illustrated in the following examples:

(6) It was very hard to leave.

(7) I am very open with my feelings.

(8) That was very nice of you.

(9) She is very good at gymnastics.

The next patterns are those consisting of the collocations of degree adverbial very and adverb collocates. Consider the following examples: 
(I0) Time goes by very quickly.

(II) The blood very slowly dripped out.

(I2) Tennessee is very much different from Kentucky.

Those examples illustrate how the collocation can be positioned either after or before the modified verb, while it can only be positioned before the modified adjective. In all these mentioned patterns, the function of degree adverbial very does not change. Here it is noted that a slightly different function will arise when a different pattern of co-occurrence is formed, when the collocations co-occur with a negative value. Take a look at the following example:

(I3) My mom was not very happy with me.

In example 13, the collocation is preceded by negative value not resulting in the function of the degree adverbial very to be altered. Degree adverbial very which is supposed to intensify the degree of the adjective is turned into having the function of lessening it, while the adjective happy can be referred as mad as in, 'My mom was rather mad at me'.

\section{The Collocations of Degree Adverbial Really}

Move to the second degree adverbial, 329.338 occurrences of really in Blog Authorship Corpus were found. It is almost as twice as the total occurrence number of very. The following table displays said collocates (the following collocates have the co-occurring frequency of 300 or above and are listed in descending order of said frequency):

Table 2

The Collocates of Degree Adverbial 'Really'

Collocates

good, really, want, like, need, nice, cool, bad, know, hard, think, wanted, care, well, funny, great, fun, hope, liked, tired, love, happy, excited, long, hate, enjoyed, weird, sad, wish, cute,

Degree adverbial sure, interesting, miss, hot, sucks, matter, enjoy, wanna, big, boring, pissed, mean, thought, bored, stupid, close, fast, needed, quite, wants, felt, sick, busy, remember, sorry, say, into, awesome, important, understand, glad, believe, appreciate, very, annoying, sweet, pretty, hurt, mad, late, upset, loud, old, easy, fucking, so, needs, likes, cares, knows, interested, early, worth, enjoying, matters, short, scared, strange, suck, done, amazing, scary, neat, loved, cold, hurts, worried, angry, hoping, sucked, there, drunk, exciting, high

Despite being on the same page with degree adverbial very as amplifiers, a different result for degree adverbial really emerges from the corpus as shown in Table 2. However, similar to very, it is noted that in its occurrences, the collocations were found either at the end of the clause or in the middle of the clause. From the corpus, the collocates of degree adverbial really consists of words coming from either verb, adjective, adverb or preposition word class. The pattern of co-occurrence is known when the collocations of degree adverbial really and verb collocates are placed in the middle of the clause and followed by either a noun, infinitive or prepositional phrase. Take a look at the following examples:

(I4) We really know our stuff.

(I5) They really want to come.

(I6) I really care for you.

Additionally, a further investigation shows that in a significant number of tokens in the corpus, the collocations are also often to be accompanied by either auxiliary or modal verb resulting in the another pattern as in: 
(I7) They do really hate me.

(18) We would really appreciate some extra our way.

In these two mentioned tokens, do and would are seen to precede the collocation in each token respectively. With really has the meaning of 'to a great extent' or 'very much', really expresses a function as degree adverbial in both tokens. The next pattern is where the collocation co-occurs with a negative value. In a similar manner to that of very, the function of degree adverbial really will be slightly altered as in the example below.

(I9) I don't really feel like writing today.

In example 19, negative value not exists accompanying do to co-occur with the collocation. If we look at it, the meaning of the sentence in the example more or less is 'I am not in the mood for writing today'. This illustrates that the function of degree adverbial really is altered because instead of intensifying the verb phrase feel like, really lessens or even opposes it. Interestingly, what is stated in LDOCE is that the phrase 'feel like (doing) something' is often used in spoken English and the same thing goes to wanna which also one of the verb collocates that really has. Wanna is a short form of 'want to' or 'want a' which is more of spoken language. Move to the next pattern, in which the collocations of degree adverbial really and adjective collocates occurring at the end of the clause. Either noun complimented by linking verb or noun complimented with verb and pronoun is found to precede the collocation. Consider the following examples:

(20) Teenagers get really excited.

(2I) Sometimes I found them really funny.

Furthermore, from the tokens, really can be rather tricky. It is because while the collocation occurs in the middle of the clause and co-occurs with a noun phrase, a determiner was found to be positioned either before or in-between the collocation, like in the examples below:

(22) It is a really well-maintained school.

(23) I'm really a bad person.

It is tricky because, in the two mentioned examples, two different functions of really are illustrated. The former example illustrates the function of really as adjective modifying degree adverbial. Whereas the latter illustrates the function of really as a manner adverb by having the same sense to 'truly' to emphasize the statement or the opinion of the writer. Consequently, in the majority of occurrences where any verbs or auxiliary verbs exist in the sentence, a determiner is positioned before the collocation, as in:

(24) She did a really good job.

(25) We got a really cool robot vacuum cleaner.

The next patterns are those where the collocations can be followed by either prepositional or infinitive phrase. Take a look at the following examples:

(26) The rehearsal was really fun for some reason.

(27) I'm really sick of all this bullshit.

(28) It was really hard to concentrate. 
The next patterns to be identified consists of the collocations of degree adverbial really and adverb collocates. It is noted that different from that of degree adverbial very, the adverb collocates of degree adverbial really are mostly emphasizer. Consider these examples:

(29) Friday night was really very fun.

(30) It's really fucking hard to type.

In those examples, the writers use very and fucking respectively to emphasize his/her statement to a certain degree. The collocations were found to precede the modified adjectives. Move to the last pattern, the collocations of degree adverbial really and preposition collocate into were found to be followed by a noun, as in:

(3I) I am really into politics.

\section{The Collocations of Degree Adverbial 'Quite'}

The finding from WordSmith 4.0 shows 57.382 tokens of quite from Blog Authorship Corpus. The collocates for quite are presented below (the following collocates have the co-occurring frequency of I00 or above and are listed in descending order of said frequency):

Table 3

The Collocates of Degree Adverbial 'Quite'

Collocates

sure, good, well, fun, nice, interesting, frankly, funny, possibly, like, happy, often, right,

Degree Adverbial sad, different, boring, amusing, nicely, awhile, excited, simple, easy, cool, know, proud, 'quite'

late, long, busy, tired, hard, ok, entertaining, understand, literally, surprised, simply, get, honestly, impressed, difficult, pleased, early, ready, true, enough, clear, remember, enjoyable, make, scary, possible, easily, obvious, bad, annoying, close, amazing, strange, cute, upset, impressive, exciting, bored, fit

Table 3 shows that slightly similar to those of degree adverbial really, the collocates of degree adverbial quite are noted to be more various than very. In its occurrences, it is noted that the collocations were found mostly either at the end of the clause or in the middle of the clause. It is observed that the collocates of degree adverbial quite consists of words coming from either adjective, adverb or verb word class. The first pattern to be identified is when the collocations of degree adverbial quite and adjective collocates are placed at the end of the clause with either noun complimented by linking verb or noun complimented with verb and pronoun precedes the collocation. See the following example:

(32) The story is quite good.

(33) I find that quite rude.

Following this, the next patterns emerge when the collocations were found to be in the middle of the clause. The collocations are followed by a noun phrase, in which a determiner is placed either before or after the collocation slightly similar to the previous case of degree adverbial really. Consider examples:

(34) It's a quite funny thing.

(35) We had quite a long chat to catch up.

However, it is noted that different from the case of degree adverbial really, one of the patterns is still considered as something grammatically acceptable while illustrating a different function of really. In the case of degree adverbial quite, one of the patterns is considered to be grammatically incorrect. Said 
pattern is the one from Example (34), the pattern is considered as grammatically incorrect. It is because according what LDOCE noted, the correct grammar is that we have to put quite before a determiner, not after the determiner. Hence, the existence of occurrences with this pattern in the corpus indicates that the language in blog does not always abide by the grammar rules. Next, although the number of occurrences is rare, it is also found that the collocations are able to be followed by either prepositional or infinitive phrase. Take a look at the following examples:

(36) Basically, they are quite easy to do.

(37) This is quite true in the case of Pakistan and India.

Before going further, in example (36), quite is supposed to lessen or weaken the quality of easy, it is just as noted in Paradis (1997, p.86) patterns of combination, since the adjective used in the sentences is the scalar one, then the function of degree adverbial quite is to lessen or weaken the strength of a node. Hence, in the example, the writer expresses a slight quality of easy. While on some occasions, quite could mean the opposite. Consider the latter example (37), the tokens contain a limit adjective, in which according to Paradis (1997, p.78) contributes in affecting the function of quite. Therefore, with true counted as a limit adjective, quite in example 37 is used to amplify the word true. Move to the next pattern, which is formed when degree adverbial quite co-occurs with adverb collocates. In their occurrences, the collocation can be positioned after the modified verb, as in,

(38) It fits quite nicely.

or before the modified verb, like in the example:

(39) This quite often happens.

It is asserted previously that the collocations of degree adverbial quite mostly occurs in medial position. It is because in a number of occurrences, the collocations of degree adverbial quite and adverb collocates were found to also occur in initial position. Consider examples:

(40) Quite frankly, I feel sorry for the kids.

(4I) Quite literally, the more the merrier!

The next pattern consists of the collocations of degree adverbial quite and verb collocates. Similar to really, in co-occurring with these verbs, either auxiliary or modal verb was often found to accompany the collocation. However, in degree adverbial quite, said auxiliary and modal verbs are all in their negative form. Take a look at these examples:

(42) I don't quite like Liverpool.

(43) I don't quite know the whole story.

(44) I can't quite get it sometimes.

In all of these tokens, negative value not is seen to accompany the auxiliary and modal verbs and the existence of this negative value can alter the function of degree adverbial quite. In examples 42, 43, and 44 one cannot simply interpret the function of quite in said token as something to weaken or lessen because the context would not fit in. Therefore, based on the context, quite should be interpreted to have the function as to how very or really does. 


\section{The Collocations of Degree Adverbial Pretty}

From the collection of the data, a total of 89.294 tokens of occurrences were found in Blog Authorship Corpus. It can be seen in the following table (the collocates have the co-occurring frequency of 100 or above and are listed in descending order of the said frequency):

Table 4

The Collocates of Degree Adverbial 'Pretty'

\begin{tabular}{|c|c|}
\hline & Collocates \\
\hline $\begin{array}{l}\text { Degree adverbial } \\
\text { 'pretty' }\end{array}$ & $\begin{array}{l}\text { much, good, cool, sure, well, funny, damn, fun, bad, boring, soon, nice, interesting, hard, } \\
\text { easy, darn, busy, big, happy, close, decent, awesome, excited, sweet, tired, fast, quickly, sad, } \\
\text { late, hot, amazing, neat, great, long, crazy, early, cute, obvious, weird, stupid, lame, high, } \\
\text { fucking, uneventful, exciting, simple, normal, quick, scary, pissed, quiet, far, clear, crappy, } \\
\text { little, impressive, sick, bored, low, small, tough, ok, slow, proud, badly, shitty, short, smart, } \\
\text { confident, entertaining, rough, accurate, pathetic, nifty, strong, ugly, tight, nasty, serious, } \\
\text { cheap, upset, intense, new, damned, dumb, solid, young, easily, old, dull, heavy }\end{array}$ \\
\hline
\end{tabular}

The list above illustrates a clear summary of the collocating words of degree adverbial pretty. Similar to the previous degree adverbials, it is found that in its occurrences, the collocations are placed at the end of the clause or in the middle of the clause. From the corpus, it is noted that the collocates of degree adverbial very consists of words coming from either adjective or adverb word class. The first pattern to be identified is when the collocations of degree adverbial pretty and adjective collocates are placed at the end of the clause with either linking verb or transitive verb complimented by pronoun or noun is positioned before the collocation, as in:

(45) My new bathroom floor looks pretty good.

(46) I got home pretty early.

The second pattern then emerges when the collocations are placed in the middle of the clause. The said collocations can be followed by a noun phrase, in which a determiner is found to be positioned before the collocation, as in,

(47) I had a pretty good weekend.

or it may be followed by either infinitive or prepositional phrase. Consider these examples:

(48) They were all pretty happy to see me back.

(49) I have considered myself pretty resistant to change.

(50) She's also pretty nifty with screwdrivers.

The next pattern are that consisting of the collocations of degree adverbial pretty adverb collocates. It is noted that the collocates in this pattern can be divided into those which describe a manner and those which used to emphasize something. For the former category, take a look at the following examples:

(5I) I consumed them pretty quickly.

(52) I am pretty easily swayed.

These examples illustrate that the collocation can be positioned either before or after the modified verb. Whereas for the latter category, adverbs of emphasis which usually used in spoken informal context mostly appeared. In this pattern, the collocation is positioned before the modified adjective. Consider the following examples taken from the corpus: 
(53) He's also pretty damn attractive.

(54) This weekend was pretty fucking intense.

If we look at these two examples, the presence of these adverbs in the sentences affects how degree adverbial pretty work. In both examples, degree adverbial pretty is no longer used to weaken or lessen because the context would not fit.

\section{The Semantic Prosody of Degree Adverbial 'Very, Really, Quite, and Pretty'}

Due to the enormous size of the corpus and the high frequency of each degree adverbial, only tokens of top 100 collocates of each degree adverbial were investigated. The top IOO collocates were chosen because they have a major part in percentage which can lead to the result. Furthermore, it is because the semantic prosody itself is determined based on the total frequency of the meaning of collocation dominate the occurrences.

A number of collocates which co-occur with each degree adverbial have been discussed that show us a rather undefined prosody through co-occurring with pleasant, unpleasant, and neutral words. However, a more specific result was found after their expanded context was explored. Here, a table presents the specific number between each pleasant, unpleasant and neutral meaning collocates.

Table 5

The Frequency of Semantic Prosody of 'Very, Really, Quite, and Pretty'

\begin{tabular}{|c|c|c|c|c|}
\hline KWIC & Pleasant & Neutral & Unpleasant & Total \\
\hline very & $39 \%$ & $36 \%$ & $25 \%$ & $\begin{array}{c}\text { I00 out of } 4533 \\
\text { possible } \\
\text { collocates }\end{array}$ \\
\hline really & $30 \%$ & $24 \%$ & $46 \%$ & $\begin{array}{c}\text { I00 out of } 6337 \\
\text { possible } \\
\text { collocates }\end{array}$ \\
\hline quite & $44 \%$ & $31 \%$ & $25 \%$ & $\begin{array}{l}\text { I00 out of 2I3I } \\
\text { possible } \\
\text { collocates }\end{array}$ \\
\hline pretty & $33 \%$ & $37 \%$ & $30 \%$ & $\begin{array}{c}\text { I00 out of } 2527 \\
\text { possible } \\
\text { collocates }\end{array}$ \\
\hline
\end{tabular}

The table tells us that each degree adverbial has different percentages on their pleasant, neutral, and unpleasant collocations. Out of their top $\mathrm{IOO}$ collocates, pleasant meaning dominates the most on degree adverbial very and quite, meaning that both of them have a favourable semantic prosody. As degree adverbial really is favored by unpleasant meaning collocations, they lead degree adverbial really to an unfavourable semantic prosody. On the other hand, degree adverbial pretty tends to have neutral meaning collocates in most of its occurrences. The following discussion is related to what collocates fill each pleasant, neutral, and unpleasant column and a detailed list of their categorization are attached to the appendices. However, it has to be noted that the categorization of each collocate is based on their context in collocating with each degree adverbial, hence the difference in the categorization of overlapping collocates in each degree adverbial is not impossible.

In the second column of Table 5, all degree adverbials collocate with pleasant meaning collocates, in which several of them are noted to be the same. Gathered from the pleasant column on four appendices, the said collocates for each degree adverbial are words like good, nice, cool, well, interesting, sure etc. By looking at these words themselves, all of them can be easily identified to have a pleasant meaning which leads to a favourable semantic prosody. It is shown in the concordance lists that each degree adverbial is collocating with these words to intensify the pleasant or favourable quality of something. For example, in 
degree adverbial very, the collocates good and nice are found to occur in phrases like good, advice, good guy, good terms, good mood, good (at doing something), nice day, nice food, nice place, etc. are found.

The word cool in the corpus is found to describe the appearance of something or the personality of someone rather than referring to temperature. The said word is used in the same way as good and nice in which they are meant to be something pleasant. Hence why phrases like cool movie and cool guy are found in the concordance list. On the other hand, well which have a pleasant meaning by itself, is making those collocating with the said word to have a pleasant meaning. It can be seen from the corpus, where phrases as in well aware, well behaved, well-constructed, well deserved, well done, well mannered, well organized, well researched, well written, etc. are found.

In the corpus, interesting is counted to have pleasant meaning because the word interesting is used in complement to describe something pleasant as in interesting and cleverly done, interesting and informative specifying the meaning of interesting to be something pleasant in its occurrences. A special case, however, occurs with the word sure, the said word means something pleasant in one way and unpleasant in another. As depicted in the corpus, when sure collocates with degree adverbials very and pretty, it refer to 'no doubt'. However, when it co-occurs with degree adverbial quite, it mostly refers to the opposite by frequent co-occurrence with a negative value not in the phrase 'not quite sure'.

In the third column of the table, each degree adverbial co-occurs with neutral meaning collocates. Derived from all neutral column on four appendices, this particular column is filled with words like long, important, close, strange, etc. to collocate with each degree adverbial. These words can be referred to as "neutral" because they are either mostly undefinable in their co-occurrence or they tend to collocates with other words resulting in both pleasant and unpleasant meaning. For example, the word long is considered to be neutral because unless it co-occurs with other words in a particular context like how phrases long and tiring or long and boring, the word long does not indicate any specific meanings. This case also applied to other words in the column. Another example is the word close. In the corpus, the meaning of the word close can be undefinable due to both pleasant and unpleasant co-occurrence. Take for example:

(55) I'm very close with my brother.

(56) I'm tired, frustrated, and very close to depression.

In the former example, the meaning of close is pleasant because it depicts the good relationship between the writer and his/her brother. Whereas in the latter, it can be seen that the meaning of close is unpleasant because it refers to how close the writer to experience depression, a mental illness.

On the other hand, rather than co-occurring in contexts with both pleasant and unpleasant meaning, the word important is shown to have no particular tendency of meaning in any context. It is used merely to describe the priority level of something. Hence why the researcher found no implication whether the meaning of the word is pleasant or unpleasant and settled with neutral instead. It is illustrated by phrases like important lesson, important information, important issues, etc. which are found in the concordance list. The word strange and its synonyms odd and weird also has the same case. As they are found in phrases like strange dream, strange feeling, and strange thing, they do not imply any meaning whatsoever and are used only to point something unusual and out of ordinary.

Clearly defined unpleasant meaning words like hard, bad, sad, tired, etc. are noted to occupy the fourth column of table 5. It can be seen in the unpleasant column of all four appendices. Just like how pleasant words are, these words clearly have unpleasant meaning by themselves in which bad is used to describe the quality of something, it was found in phrases like bad attitude, bad day, bad mood, etc. As seen in the concordance list, all these tokens mostly have unpleasant meaning regardless of the lexical items which followed the word bad. The same goes for the words sad and tired because it is obvious that both words refer to an unpleasant or negative emotion of human being.

Different from the previous words which are obviously found to have unpleasant meaning, the word hard is sometimes found to co-occur in contexts where the meaning hard is pleasant. As derived 
from the corpus, phrases like hard working, hard worker, work hard all have pleasant meaning. However, the word hard was categorized as unpleasant because the number of the pleasant co-occurrence are not as comparable as the unpleasant one where hard is found in phrases like hard time, hard thing, hard to (do), hard for (me), etc.

\section{Discussion}

From hundred thousand of tokens derived from the corpus, the various collocates and patterns for each degree adverbial have been found. The patterns are all based on each of their collocate groups. It is different from the previous studies which analyzed only the adjective collocates of degree adverbials without their pattern of co-occurrence, this study covers all collocates of the degree adverbials which correspond to this research limitation as well as their collocations' pattern of co-occurrence.

Based on the finding, several differences were found regarding each degree adverbial. The first one is regarding the variety of their collocates. All degree adverbials are found to share a large number of same words to collocate with coming from the same word classes, adjectives and adverbs. However, the researcher noted that only degree adverbials really and quite were found to also collocate with words from the word class of verb. The researcher assumed this happens because degree adverbials are primarily used in modifying adjectives and adverbs. Additionally, only three out of four degree-adverbials were found to also collocate with negative value, namely very, really, and quite, in which, when this collocation happened, the function of said degree adverbials will be slightly altered.

The second one is regarding their collocations' patterns of co-occurrence. Different types of collocations resulting in different pattern of collocations' co-occurrence. However, in a further investigation, it is noted that in several cases, different patterns of co-occurrence emerge even from the same type of collocations which owned by the four degree adverbials. For example, in collocating with adjective collocates, all degree adverbials were found to be either at the end of the clause or in the middle of the clause followed by noun, infinitive or prepositional phrase. Yet, in a specific occurrence where their collocations co-occur with a noun phrase, their patterns of co-occurrence are slightly different.

The former aspect happened in the case of degree adverbial quite because of the different grammatical structure the said degree adverbial has as the researcher observed that occurrences with the first pattern are considered to be ungrammatical. On the other hand, the latter aspect happened in the case of degree adverbial really, in which its second collocations' pattern of co-occurrence is that a determiner was found exist in between the collocations. Different from the case of quite, this pattern is not considered to be ungrammatical but rather it illustrates the flexibility of function for degree adverbial really. It is acceptable to write 'I'm really a bad person' with really functions to emphasize the statement, but it is unacceptable to write 'It is very an interesting album'. Moreover, in co-occurring with either infinitive or prepositional phrases, degree adverbial quite is shown to be slightly restricted in this respect as their amount of total occurrences is the least among the four.

Following the previously mentioned difference of pattern, in co-occurring with adverb collocates it is found that all four degree adverbials are mostly found to occur in medial position. In a number of occurrences, however, one degree adverbial were found to be different as it also able to occur in frontal position, resulting the collocations to be also in the same position aside from being at the end or in the middle of the clause. The said degree adverbial is quite. Furthermore, it is found that their collocations can be placed either before or after the modified verbs, while if the collocation co-occurs with adjectives, it was placed to precede the modified adjectives. As for the pattern of co-occurrence, the researcher found only one pattern of said collocation in degree adverbial really whereas those of other degree adverbials are more vary. The researcher assumed that this depends on the types of adverb collocates that each degree adverbial has.

The next example coming from occurrences where two out of four degree adverbials were found to frequently collocate with verbs. The only degree adverbial to collocate with verb collocates are really and quite. Still, even if the both of them share the same verb collocates, in their occurrences, they are 
notably different. The patterns of said collocations in degree adverbial really are more vary than that of degree adverbial quite as they were formed either in the presence of auxiliary verbs or in the absence of them. It is illustrated in the corpus by example (I4) and (I7), as it is written 'We really know our stuff' and 'They do really hate me'. On the other hand, the pattern of said collocation of degree adverbial quite is more restricted than that of degree adverbial really as the pattern was formed in the presence of auxiliary verbs and negative value. It can be seen from the example (42), 'I don't quite like Liverpool'.

Aside from the patterns of co-occurrence, all degree adverbials were found to have a wide semantic preferences for their adjective collocates. It varies from general evaluation (good, well, nice, bad, cute, etc), emotion or state of mind (happy, interested, sad, tired, confused, etc), quality (long, big, fast, slow, short, etc). However, it is noted that there is one degree adverbial to have an even wider semantic preferences by also collocating with quantity adjectives (few and little), that is degree adverbial very. It is different from Zhang (2013); Simpson \& Mendis (2003); Nakatani \& Hirschberg ( 1994); Deroey \& Taverniers (20I I); Charles (2006); Bolton, Nelson, \& Hung (2002), in which only degree adverbial awfully has the wide semantic preferences while degree adverbials terribly, horribly, and dreadfully all typically co-occur with adjectives describing emotions or state of mind. Those adjectives are sorry, miss, upset, worried, bored, disappointed, embarrassed, suffer, afraid, aware, and dull.

In addition, each degree adverbial was found to have their own semantic preferences for their adverb collocates. Degree adverbials very and quite were mostly found to co-occur with adverbs of manner. The former collocates with quickly, slowly, easily, badly, nicely, etc, while the latter collocates with possibly, frankly, honestly, simply, etc. On the other hand, degree adverbial really shows a clear tendency to only co-occur with adverbs of emphasizer like really, just, very, fucking, etc. Whilst degree adverbial pretty was found to collocate with both types of adverbs, emphasizer and manner such as damn, darn, fucking, quickly, badly, etc.

Correspondingly, Watcher (2012) shows that very is favored by lecture type environment which is mostly formal. In a similar manner, the finding of this study supports and complements the statement as the researcher found that rather than very and quite, really as well as degree adverbial pretty is often used in informal context, seeing the total number of occurrences found in Blog Authorship Corpus, a corpus of blog posts compilation.

In addition, degree adverbials really and pretty are noted to have similar collocates. It is interesting because really and pretty are supposed to have a different function, in which really functions to strengthen while pretty functions to do the otherwise. As illustrated in the corpus, really was found to co-occur with a verb like wanna and adverb like fucking, whereas pretty collocates with adverbs like fucking, damn as well as darn. In which, this indicates that really and pretty are often used in the same genre. The researcher supposed that it is in accordance to what is written in LDOCE, in which really and pretty are especially frequent used in spoken English because people usually go for very or extremely instead of really and fairly instead of pretty for written English. Hence, it also indicates that the users of the internet (or blog) prefer to use spoken language even in a supposedly written platform. The researcher also found other collocates which indicate informal language co-occurring with degree adverbials really and pretty. They are included in the class of adjective and are usually impolite or even categorized as taboo. Those words are sucks (refer to something lousy), crappy, shitty, fucked, and messed up.

As for the semantic prosody of each degree adverbial, it is found that very and quite are favored with pleasant semantic prosody. The finding shows that both of them are mostly dominated by adjectives with pleasant meaning as their collocates. Whereas unpleasant for degree adverbial really. It is slightly different from the result of the previous study conducted by Watcher (2012) which states that degree adverbial really was more leaning towards both favourable and unfavourable semantic prosody. As for the last degree adverbial, pretty has neutral semantic prosody because of the domination of neutral words. 


\section{CONCLUSION}

It is known in the analysis that all degree adverbials collocate with various words from both adjective and adverb word classes. Whereas only two out of four degree adverbials collocate with other words from different word class. In their occurrences, all degree adverbials were found mostly to be in medial position and their collocations can happen mostly either at the end of the clause or in the middle of the class. Only their collocations differ, resulting in several different patterns of co-occurrence in accordance to their collocations.

Furthermore, two out of four degree adverbials are seen to have pleasant semantic prosody, and the other two have unpleasant and neutral for each of them. With a total $39 \%$ pleasant meaning collocates, the biggest percentage of all, degree adverbial very is clearly illustrated to have pleasant semantic prosody. The same goes for degree adverbial quite which has $44 \%$ of pleasant meaning collocates out of 100 . Degree adverbial really, however, has a rather significant number for unpleasant meaning collocates, $47 \%$. It is almost like the half of the total number, notably being the biggest compared to its pleasant and neutral meaning collocates which only have $29 \%$ and $24 \%$ respectively. As for the last degree adverbial, pretty, neutral meaning collocates are seen to dominate the chart with $37 \%$ in total.

Since this corpus is non-annotated, the collocates are highlighted and categorized, hence there may be some possibilities for error. To conduct a more thorough and clear research can be expected by using an annotated corpus or another corpus with a more considerable size. Also, as a reminder for the future researcher, it has to be noted that corpus is not only can be used as a way to investigate the semantic prosody of a node. More than that, from the collocation, it is always possible to investigate any patterns of co-occurrences like one the researcher had done with very, really, quite, and pretty. It is also possible to further the research by investigating the factors which may affect the use of these degree adverbials in the future while there are also numerous other parts of speech that can be investigated by using corpus.

\section{ACKNOWLEDGMENT}

The writers owe their gratitude to a fellow researcher, Mr Zhang, who has kindly given the copies of material about degree adverbials which could not be found anywhere.

\section{REFERENCES}

Barnfield, K., \& Buchstaller, I. (2010). Intensifiers on Tyneside: Longitudinal developments and new trends. English World-Wide, 3I(3), 252-287. doi: I0.1075/eww.3I.3.02bar

Begagic, M. (2013). Semantic preference and semantic prosody of the collocation 'make sense'. Ezikoslovlje Journal, Zenica: University of Zenica.

Biber, D., S. Conrad, and G. Leech. (2002). The Longman Student Grammar of Spoken and Written English. London: Longman.

Bolton, K., Nelson, G., \& Hung, J. (2002). A corpus-based study of connectors in student writing: Research from the International Corpus of English in Hong Kong (ICE-HK). International Journal of Corpus Linguistics, 72), I65-I82. doi: https://doi.org/I0.1075/ijcl.7.2.02bol

Carter, R., McCarthy, M., Mark, G., \& O’Keeffe, A. (20II). English grammar today: An a-z of spoken and written grammar. Cambridge: Cambridge University Press.

Charles, M. (2006). Phraseological patterns in reporting clauses used in citation: A corpus-based study of theses in two disciplines. English for Specific Purposes, 25(3), 310-331. Doi: https://doi.org/I0.1016/j.esp.2005.05.003

Deroey, K., \& Taverniers, M. (20II). A corpus-based study of lecture functions. Moderna språk, IO5(2), $\mathrm{I}-22$. Retrieved from: http://ojs.ub.gu.se/ojs/index.php/modernasprak/article/view/793/827

Firth, J. R. (1957). Papers in Linguistics: 1934-1951. London: Oxford University Press.

Gonzales-Diaz, V. (20I4). I quite detest the man: Degree adverbs, female language and Jane Austen. Language and Literature, 23(4), 310-330. doi: I0.I I77/09639470I4534I23

Huo, Y. (2014). Analyzing collocation errors in EFL Chinese learners' writings based on corpus. 
Nanchong: School of Foreign Languages China West Normal University.

Jones, C., \& Waller, D. (2015). Corpus linguistics for grammar: A guide for research. London: Routledge. Long, L. N., \& Christensen, W. F. (2008). Clearly, using intensifiers is very bad - or is it? Retrieved from: http://works.bepress.com/lance_long/I

Louw, B. (1993). "Irony in the text or insincerity in the writer? The diagnostic potential of semantic prosodies”. In M. Baker, G. Francis, \& E. Tognini-Bonelli (Eds.), Text and technology: In honour of John Sinclair (pp. I57-176). Amsterdam: John Benjamins.

Nakatani, C. H., \& Hirschberg, J. (I994). A corpus-based study of repair cues in spontaneous speech. The Journal of the Acoustical Society of America, 95(3), 1603-1616. doi: https://doi.org/I0.II2I/I.408547

Nilsson, S. (2003). The Function of Language to Facilitate and Maintain Social Networks in Research Weblogs. Umea Universitet, Engelska Lingvistik.

Nowson, S. (2006). The Language of Weblogs: A study of genre and individual differences. Edinburgh: University of Edinburgh.

Partington, A. (2004). Utterly content in each Other's Company. Amsterdam: John Benjamins.

Quirk et al. (1985). Grammar of Contemporary English. London: Longman.

Reicheld, S. \& Durham, M. (2017). Adjective intensification as a means of characterization: portraying in-group membership and Britishness in Buffy the Vampire Slayer. In: Journal of English Linguistics, Vol. 45, No I. Retrieved from: https://journals.sagepub.com/doi/abs/I0.I I77/0075424216669747

Simpson, R., \& Mendis, D. (2003). A corpus-based study of idioms in academic speech. Tesol Quarterly, 37(3), 4I9-44I. doi: https://doi.org/I0.2307/3588398

Sinclair, J. (2003). Reading Concordance. London: Pearson Education Limited.

Stubbs, M. (1995). Collocations and Semantic Profiles: on the Cause of the Trouble with Quantitative Methods. Function of Language 2(I), I-33. Amsterdam: John Benjamins.

Watcher, A. R. (2012). Semantic Prosody and Intensifier Variation in Academic Speech. M.A. Thesis. University of Michigan, Athens, Georgia.

Yilmaz, E. \& Dikilitas, K. (2017). EFL Learners' Use of Adverbs in Argumentative Essays. NovitasROYAL (Research on Youth and Language), II(I), 69-87.

Zhang, R. (2013). A Corpus-based Study of Semantic Prosody Change: The Case of the Adverbial Intensifier. Concentric: Studies in Linguistics, 39(2), 6I-82.

Zhiber, E. V., \& Korotina, L. V. (2019). Intensifying adverbs in the English language. Training, Language and Culture, 3(3), 70-88. doi: 10.29366/2019tlc.3.3.5 